\title{
Some Mechanical Properties of Cement Treated Base (CTB) In- corporating waste Portland Cement Concrete Under Different Corresponding Conditions
}

\author{
Asst. Prof. Dr. Khawla H. H. Shubber ${ }^{*}$, Eng. Sajjad Hashim Mohamed ${ }^{2}$ \\ ${ }^{1,2}$ Engineering faculty/University of Kufa / Iraq \\ *Corresponding author E-mail: khawla..shubber@uokufa.edu.iq
}

\begin{abstract}
This research represents a trial of understanding and improving mechanical properties of base or subbase granular materials, used in pavement construction, stabilized with Portland cement known as cement treated base (CTB) in terms of density, optimum water content (O.W.C), and compression Strength of three curing ages $(3,7,28)$ days under different situations. Different Portland cement percent of $(0,5,7,10,12$, and 15$) \%$ by weight were added to selected base course granular materials (type B according to local standard specification in Iraq). Results showed that the density of mixture increase with increasing added cement percent, while O.W.C takes its maximum value around $7 \%$ cement content, and compression strength increase with increasing cement content and curing age. Then effect of replacing $50 \%$ of natural granular materials by waste Portland cement concrete (WPCC) was investigated on the results of $(0,7 \& 15) \%$ cement content on density, O.W.C and compression strength in the three curing ages. Results reveled although density of mixture cooperating WPCC for $0 \%$ cement content was higher, CTB of natural granular material were denser. On the other hand compressive strength decrease in case of using WPCC for all percent cement added and curing ages. Finally, effect of soaking in water on CTB with (7 \&15)\% cement compressive strength of three curing ages was studied, under three period of soaking (1 week, 2 weeks, \&one month). Test results exposed that, CTB Compressive strength increase with increasing soaking period but still less than that of un-soaked and for all curing ages. For each test stage mathematics relationships with acceptable correlation were presented proofing test results tendency.
\end{abstract}

Keywords: Base course, Cement treated Base (CTB), compaction test, Compression strength, soaking in water, Sustainable engineering, and Waste Portland Cement concrete.

\section{Introduction}

Increasing demand for economical and sustainable technique for road construction trend essentially to improve soil layers mechanical and engineering properties. So, a huge need appears to use certain additives to soil structure that proven its economical and advantageous effects. Portland cement was one of the most commonly used as soil stabilizer, producing a durable mixture known as soil-cement or cement treated base (CTB) when used in base or subbase courses layer (Bulletin, 1958). In general, CTB is mean a repetitive mixture of natural soils contain/ or not aggregates with selecting amounts of Portland cement as weight percent are mixing with water, then left for hardens after being compacted in higher possible density, and cured to form a durable, strong, frost resistant paving layer. That is also known as soil base treated with cement, aggregate base treated with cement, roadbed stabilized with cement, and cement-stabilized base. CTB may be mixing onsite materials in place, or can be mixed in a special plant using same material selected (frequently synthetic aggregates). Mixedin-place CTB is compacted after mixing at the same time and place, while, "CTB mixed in a central plant is to be hauled to the area of placement in tipper lorry then placing on the roadway by using a grader, paver, or Jersey-type spreader" (Gregory, et al 2006). The structural properties of resulting CTB depend on soil/aggregate material, quantity of cement, curing conditions, and the age (India, 2016).

CTB's, in fairly design and production, have a desirable record as a reliable subbase course or base course. as an example, "in the past 27 years using of cement treated base had a growth, South Carolina in 1935 to build over 80 million square yards of CTB in The United States" (George, 1963). In 1950, Microscopic study by Bezruk (Bezruk, 1950), showed that soil have micro aggregations because of cement reaction with soil. After that the researcher deduces that reaction of cement with soil may be of a beneficial, fierce or neuter in character. Handy (Handy, 1958) studied the cause of strength gains in CTB mixtures. A theory of chemical cementation between the surface of the soil particles and the hydrated cement is proposed. "Adsorption of Hydroxyl ions by partially screened silicon ions in cement gel giving an initially weak bond, With time progressing the soil particles surface become active or 'depolarized', and then an improvement in original weak bond will take place, an increasing in the mixture strength will gradually finally". To achieve most economical cement factor for durable CTB, it is recommended to use well and dense graded aggregates/soil and provide nominal maximum size less than 3 inches $(75 \mathrm{~mm})$, so that the segregation will be significantly decreased and the finished surface will be smooth as shown in figure 1. There are instances where cement-treated permeable bases using an open or gap-graded mix are utilized under concrete pave- 
ments. Too much coarse material interferes with compaction of the matrix of finer particles. Adequate density of the fine fraction is important, for it is here that most of the cementing action takes place, forming a matrix that holds the coarser particles together (Gregory 2006).

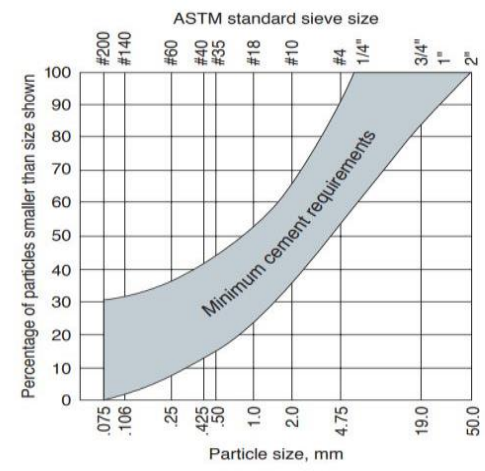

Figure 1: Minimum Cement Requirement and The Band of Aggregate Gradation(Gregory, 2006)

CTB pavements are designed for both economy and long service life. The factors analyzed to determine the CTB and surface design thickness are: subgrade strength, pavement design period, and traffic. In most cases, engineers have the option of selecting a CTB design procedure for the pavement structure according to "American Association of State Highway and Transportation Officials, 1993" (AASHTO) guide for design pavement structures (Gregory, et al ,2006). A case study was made in 2005, (Chai, et al, 2005). Where, working on at a trial section along the North-South Expressway in Malaysia. Stiffness of cement stabilized layer increase with cement increase. As provides an environmental friendly option, the recycling method of existing road base materials will not be removed. Falling Weight Deflectometer (FWD) was depended on finding in situ cement stabilized road base material stiffness. FWD was concluded to be valuable in structural valuation of the cement stabilized base layer prior to the placement of asphalt layers. Another main conclusion of test results from the FWD was also used to validate the assumed pavement design parameters. In 2010, (Guthrie, 2010) researcher worked on a case study in Brigham, USA. The prime purposes of that research were to organize construction parameters should be related to specific mechanical properties of CTB layers and to determine which construction factors display comparatively high variability within specific construction sections of the two pavement reconstruction projects. The results of this research advise that reduced spatial variability is desirable in reclaimed asphalt pavement (RAP) content, cement content, and time between mixing and compaction, which were all recognized as important predictors of CTB strength. Regarding full-depth reclamation projects, milling plans should be developed to improve uniformity in RAP content, and inspection procedures for encouraging upgraded cement content control during construction should be fulfilled to ensure high-quality work result. Compaction should be performed as soon as possible after mixing to decrease the opposing effects of cement hydration to achieve maximum dry density in the field. Decreasing variability in construction of CTB layers will ultimately lead to higher quality pavements that more consistently meet design expectations. In 2011, (Yang, 2011) worked on a case study in Australia. Portland cement treatment for base course materials results in the design of cement treated base course which is also classified as "modified" or "stabilized". The performed classifications differently in service, with susceptibility to fatigue being the most noticeable characteristic delineating them. The depended classification methodology is currently quantified based on Unconfined Compressive Strength (UCS) ranges of results. Throughout the 1990s to the early 2000s, Main Roads Western Australia has examined various base course produces created by adding cement. However, due to unpredicted behavior when adding cement treated base course materials. Evaluation done by determining the UCS increased from the cement treatment. In order, to conclude an enhanced method to compute the several classification of cement treated base course and recognize it's in situ behavior. In 2014, (Liqun, et al, 2014) a clay bricks as a waste materials from debris of buildings in China were assessed through lab tests as environmental friendly materials for pavement sub-base course. The test results specified that cement treated course materials with crushed clay brick aggregate gave a lower maximum dry density and higher optimum water content. Furthermore, UCS, resilience modulus, splitting strength, and frost resistance performance of the tested samples decreased with increase of adding present of crushed clay brick aggregate. On the other hand, it can be concluded that the adding crushed clay brick in the mixture decreased the dry shrinkage strain of the specimens. In 2016, (Shubber, 2016) an attempt of experimental study on the effect of adding Portland cement on the engineering properties of sand poorly graded river soil used as subgrade in pavement construction. The soil brought from sides of Al-Kufa River in Najaf state middle west of Iraq. Results showed that the adding of cement increase the dry density, optimum water content, direct shear strength and CBR in different rates. Also, damage developments of CTB specimens tested under different loading conditions were studied. Stress/strain state and fatigue life of materials are all related to their damage evolutions. Results from unconfined compressive tests revealed that damage evolutions of CTB specimens depended on the monotonic-compressive loading rates. Moreover, the cyclic flexural beam tests were also performed to determine the fatigue damage evolutions of CTB specimens. The test results showed that damage evolutions were depending on cyclic loading, but independent on loading waveforms. Natural logarithmic model was found to provide the most reliable values of predicted damage variable compared to the other mathematical models used in this study (Korakod \&Peerapong, 2016). Finally, Al-Jummaily et al (Al-Jummaily et al,2018). showed that, the strength of cement treated aggregate base $(\mathrm{CTAB})$ represented by California bearing ratio (CBR) and compressive strength with percent higher than those to base by $46 \%$ and $58 \%$ respectively. The using of CTAB, binder and surface course present the best economical choice of pavement structure. Mixtures having cement satisfied fewer than $10 \%$ might be used as subbase materials instead of being used in pavement base.

Current research represents one of trails searching about the best soil additive that, available, cheap, easy to handle and construction, durable, and long term effect agent. Current study aims to investigate Portland cement as stabilizer, combined with base course materials as CTB in three axes. The first axis is focusing on determining an optimal percentage of added cement according to resulting CTB's Maximum dry density, optimum water content, and Compressive strength in three curing ages ( $3,7, \& 28$ days); second axis, effect of replace $50 \%$ of aggregate by WPCC with specific gradation in selected optimum percentage of cement on CTB's Maximum dry density, optimum water content, and Compressive strength in three curing ages. Finally, studying effect of aggregate soaking in water for optimum percentage of cement on CTB's on Compressive strength in three curing ages $(3,7, \& 28$ days).

\section{Materials And Methods}

The main elements of a CTB mixture are aggregate, water and cement. These materials have been tested to determine its properties. All the tests are done according to the (ASTM specifications), (ASTM, 2003), AASHTO specifications (AASHTO,2007), and Iraqi specification (S.C.R.B., 2009). In addition to studying effect of adding WPCC to CTB course. The cement and concrete chemical and physical test specifications and results are listed in table 1 below. While, the granular material used as aggregate had the physical properties shown in table 2 . The tests of liquid limit and 
plasticity index were neglected because the soil in granular material was found as sandy soil.

Table 1: The Chemical and Physical Properties of Cement and its Specifications.

\begin{tabular}{|c|c|c|c|}
\hline $\begin{array}{l}\text { Name } \\
\text { of Test }\end{array}$ & Standard Spec*. & $\begin{array}{l}\text { S.S.I } \\
\text { Limits }\end{array}$ & Test result \\
\hline $\begin{array}{l}\text { Standard } \\
\text { consistency }\end{array}$ & (British Standrd ,12) & & $32 \%(\mathrm{w} \%)$ \\
\hline $\begin{array}{l}\text { Initial } \\
\text { setting time }\end{array}$ & \multirow{2}{*}{ (British Stanard ,12) } & $\geq 45 \mathrm{~min}$ & $88 \mathrm{~min}$ \\
\hline $\begin{array}{l}\text { Final } \\
\text { setting time }\end{array}$ & & $\geq 10$ hours & $22: 10 \mathrm{hrs}$ \\
\hline $\begin{array}{l}\text { Fineness } \\
\mathrm{cm}^{2} / \mathrm{gm} \text { by } \\
\text { Blaine } \\
\text { method }\end{array}$ & $\begin{array}{l}\text { (ASTM } \\
\text { C204-78a) }\end{array}$ & $\geq 2500$ & 4320 \\
\hline $\mathrm{SiO} 2$ & $\begin{array}{l}\text { (AASHTO, } \\
\text { M 85-041) }\end{array}$ & -- & $19.53 \%$ \\
\hline $\mathrm{SO} 3$ & $\begin{array}{l}\text { (AASHTO, } \\
\text { M 85-041) }\end{array}$ & $\leq 2.5 \%$ & $2.25 \%$ \\
\hline $\begin{array}{l}\text { Insoluble } \\
\text { Residue } \\
\end{array}$ & $\begin{array}{l}\text { (AASHTO, } \\
\text { M 85-041) }\end{array}$ & $\leq 1.5 \%$ & $0.54 \%$ \\
\hline $\begin{array}{l}\text { Loss on } \\
\text { Ignition }\end{array}$ & $\begin{array}{l}\text { (AASHTO, } \\
\text { M 85-041) }\end{array}$ & $\leq 4 \%$ & $3.98 \%$ \\
\hline \multirow{2}{*}{$\begin{array}{l}\text { Compres- } \\
\text { sion } \\
\text { strength of } \\
\text { concrete }\end{array}$} & \multirow{2}{*}{$\begin{array}{l}\text { (British Stand- } \\
\text { ard ,1881) }\end{array}$} & $\begin{array}{l}\geq 15 \mathrm{MPa} \\
\text { @ 3D }\end{array}$ & $18.4 \mathrm{MPa}$ \\
\hline & & $\begin{array}{l}\geq 23 \mathrm{MPa} \\
\text { @ 7D }\end{array}$ & $26.6 \mathrm{MPa}$ \\
\hline
\end{tabular}

*all specification related to Standard Specifications of Iraqi(S.S.I) 1984, No. $5 \& 8$

The grain size distributions of the granular materials used and S.C.R.B limits are illustrated in figure 2 , it can be say that the granular materials was Type B but with a diversion in the sieves No.50 $(0.3 \mathrm{~mm})$ and No.200 $(0.075 \mathrm{~mm})$. Consequently, correction was made to all specimens after that as attempt to comply with specification. The correction was made by adding $7 \%$ of passing of No.50 $(0.3 \mathrm{~mm})$ and $6 \%$ of passing of No.200 (0.075 $\mathrm{mm})$ by weight. The corrected aggregate gradation as compared with S.C.R.B specification represented in figure 3, aggregate complies with S.C.R.B limits for type B base course materials commonly used for pavement construction shown in table 3 .

Table 2: The Physical Properties of Granular Material Used

\begin{tabular}{|c|c|c|c|}
\hline Name of Test & Standard Spec*. & $\begin{array}{l}\text { S.C.R.B } \\
\text { Limits }\end{array}$ & $\begin{array}{l}\text { Test } \\
\text { result }\end{array}$ \\
\hline $\begin{array}{l}\text { Max. dry density } \\
\left(\mathrm{gm} . / \mathrm{cm}^{3}\right)\end{array}$ & \multirow{2}{*}{$\begin{array}{l}\text { ASTM D1557/ } \\
\text { AASHTO T180 }\end{array}$} & / & 2.05 \\
\hline $\begin{array}{l}\text { Optimum mois- } \\
\text { ture }(\%)\end{array}$ & & I & 8.05 \\
\hline CBR \% & $\begin{array}{l}\text { ASTM D1883-005 } \\
\text { /AASHTO } \\
\text { T } 193\end{array}$ & Min. 35 & 73 \\
\hline $\begin{array}{ll}\begin{array}{l}\text { Liquid } \\
(\%)^{*}\end{array} & \text { limit } \\
\end{array}$ & \multirow{2}{*}{$\begin{array}{l}\text { ASTM D } 4318 \\
\text { /AASHTO } \\
\text { T } 90\end{array}$} & Max. 25 & $\begin{array}{l}\text { Sandy } \\
\text { soil }\end{array}$ \\
\hline $\begin{array}{l}\text { Plasticity index } \\
(\%)^{*}\end{array}$ & & Max. 6 & $\begin{array}{l}\text { Sandy } \\
\text { soil }\end{array}$ \\
\hline $\begin{array}{l}\text { Gypsum content } \\
(\%)\end{array}$ & $\begin{array}{l}\text { British Standard, } \\
1377\end{array}$ & $\begin{array}{l}\operatorname{Max} \\
10.75\end{array}$ & 0.178 \\
\hline
\end{tabular}

* The tests of liquid limit and plasticity index were neglected

It will be known, that the current study is dealing with sustainable engineering concepts by using wasted materials, these materials are WPCC. Large combination of these materials was brought and fragmented in smaller parts. Table 4 shows the gradation of WPCC used in study and gradation of 50\% mixed aggregate.

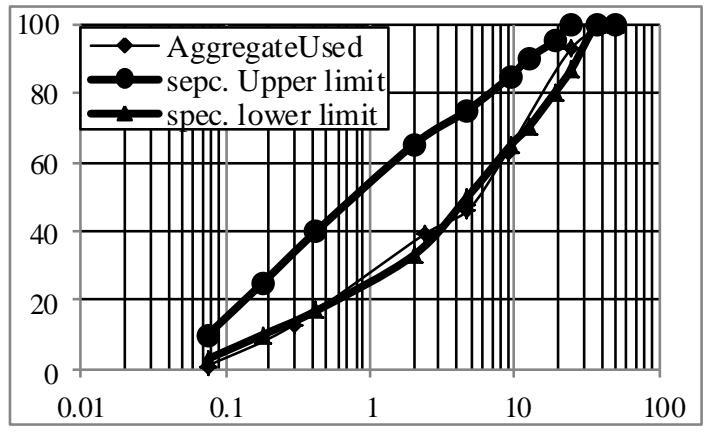

Figure 2: Gradation of Granular Material Used and Specification limits

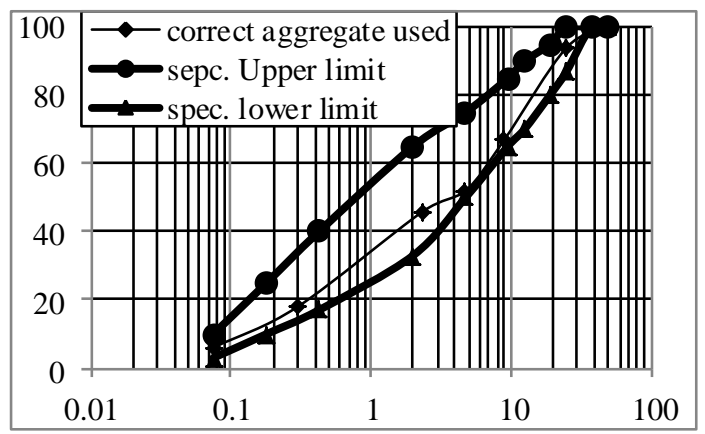

Figure 3: Corrected Gradation of Granular Material Used and Specification limits

Table 3: Specification of Base Materials (S.C.R.B.)

\begin{tabular}{|c|c|c|c|c|c|}
\hline \multicolumn{2}{|c|}{$\begin{array}{c}\text { Use sieve } \\
\text { size }\end{array}$} & \multicolumn{4}{|c|}{ Percent passing by weight } \\
\hline $\mathrm{Mm}$ & Imperial & Type A & Type B & Type C & Type D \\
\hline 75 & 3 in & 100 & & & \\
\hline 50 & 2 in & $95-100$ & 100 & & \\
\hline 25 & 1 in & 55- 90 & $75-95$ & 100 & 100 \\
\hline 9.5 & $3 / 8$ in & $30-65$ & $40-75$ & $50-85$ & $60-100$ \\
\hline 4.75 & No. 4 & $25-55$ & $30-60$ & $35-65$ & $50-85$ \\
\hline 2.36 & No. 8 & $16-64$ & $21-47$ & $26-52$ & $42-72$ \\
\hline 0.3 & No. 50 & $7-18$ & $14-28$ & $14-28$ & $23-42$ \\
\hline 0.075 & No. 200 & $2-8$ & $5-15$ & $5-15$ & $5-20$ \\
\hline
\end{tabular}

Table 4: Gradation of WPCC Used and 50\% Aggregate Mixture

\begin{tabular}{|l|l|l|l|}
\hline \multicolumn{2}{|l|}{ Use sieve size } & \multirow{2}{*}{$\begin{array}{l}\text { \% Passing } \\
\text { of WPCC }\end{array}$} & $\begin{array}{l}\text { 50\% WPCC } \\
\text { Mixture }\end{array}$ \\
\hline 75 & Imperial & & \\
\hline 50 & 2 in & 100 & 100 \\
\hline 25 & 1 in & 87.8 & 93.3 \\
\hline 9 & $3 / 8$ in & 31.97 & 42.54 \\
\hline 4.75 & No. 4 & 11.97 & 24.64 \\
\hline 2.36 & No. 8 & 3.77 & 15.88 \\
\hline 0.3 & No. 50 & 0.25 & 7.32 \\
\hline 0.075 & No. 200 & 0.1 & 1.3 \\
\hline
\end{tabular}

The following figure 4 presents a flowchart illustrates the experimental work. It can be illustrated the experimental work program by three general stages. First stage, depending on material classification results, compaction test and compression test in three curing ages (i.e. $3.7 \& 28$ days) for several percent of selected added Portland cement were performed. Second stage, dealing with selecting two percent's of cement one that gave higher density and 
the second that give the minimum optimum water content. These two percent's were used in compaction and compression test in three ages for studying effect of using WPCC as 50\% percent with base course aggregate. Finally, soaking a quantity of aggregate for ( 1 week, 2 weeks, and 1 month) and then testing the compression test for the soaked aggregate as a CTB for three ages

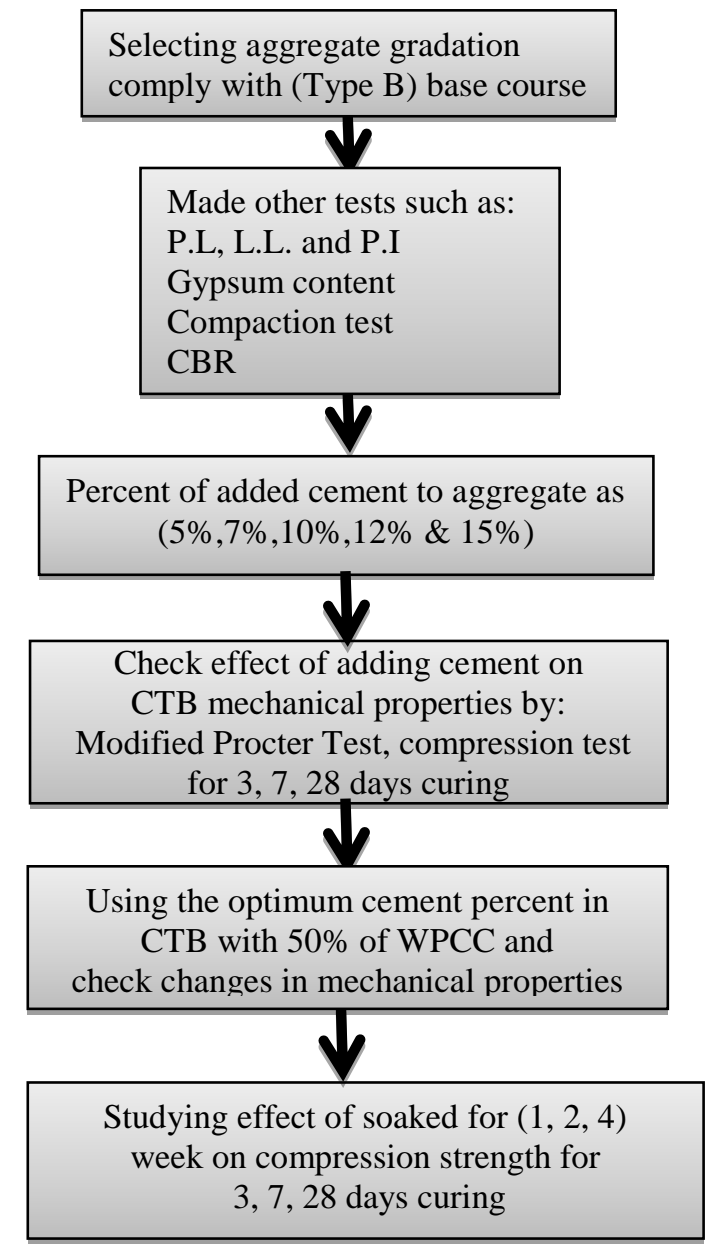

Figure 4: Experimental Work Program Flowchart

\section{Results And Discussions}

Effect of added Cement have been investigated by modified Procter test. As mentioned earlier, the selected percent of cement are, $0 \%$ for control sample, $5 \%, 7 \%, 10 \%, 12 \%, 15 \%$. Figure 5 below, illustrate the effect of increasing of cement content as a stabilizer on base course granular materials (named CTB) dry density and optimum water content. Continuous increasing in dry density with increasing cement content. The rate of increasing is in about $3.24 \%$ as average from initial value. The relationships of increasing take linear form with accepted $\mathrm{R}^{2}$ of 0.9743 and following equation:

Dry density $=0.0075(\%$ cement $)+2.0441$

The optimum water content increase with increasing cement content until reaching such value then began to decrease with increasing cement content. The maximum value of optimum water content accrue around $7 \%$ cement. The following equation No.2 with $\mathrm{R}^{2}=0.9215$ as a good indication of correlation between variables.

O.W.C $=-0.04(\text { cement } \%)^{2}+0.7($ cement $\%)+6.995$

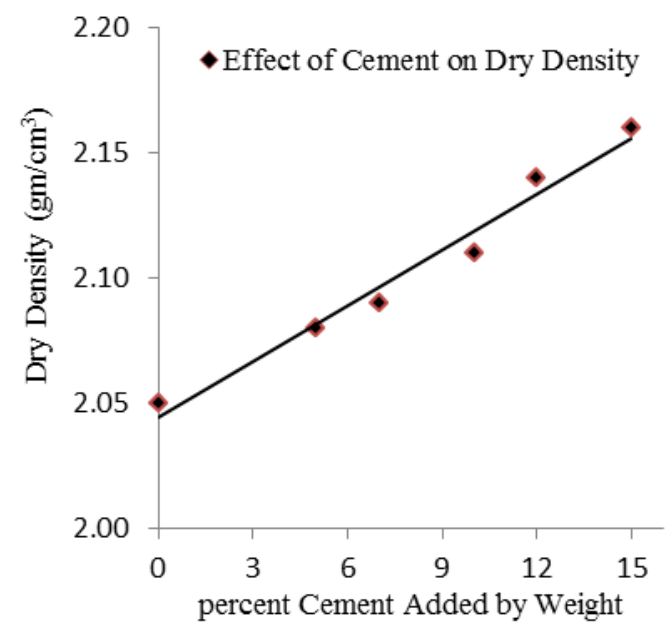

5-A Effect of Adding Cement on dry density

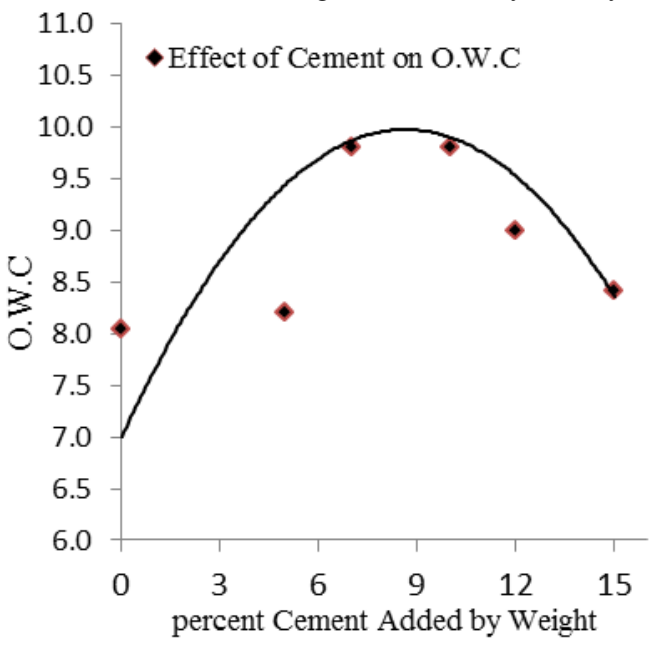

5-B Effect of Adding Cement on O.W.C

Figure 5: (A\&B) Effect of Adding Cement on Compaction Test results

Compression test performed according to (AASHTO, T22) for all selected cement percent's added. Three ages selected to test as usual, 3, 7 and 28 days for two sample for each added percent of cement. The average results of compression test for each adding cement percent shown in figure 6 illustrate continuous increasing in compression strength with increasing cement percent and curing age.

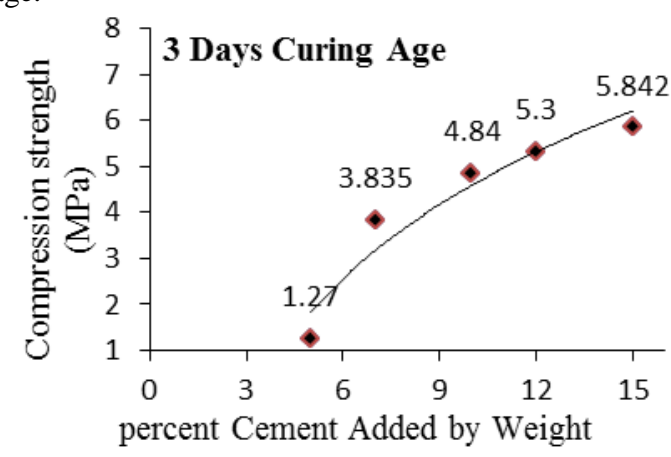



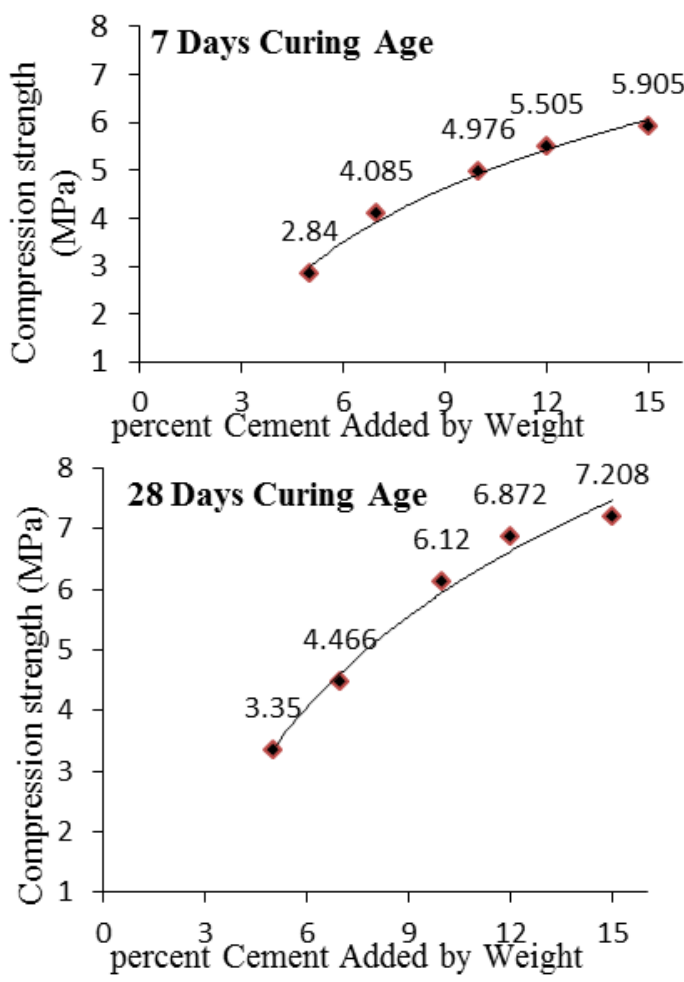

Figure 6: Effect of Adding Cement on The Compression Strength Test Rresults

The selected two percent of cement for implementation next tests are $7 \%$ and $15 \%$ that gives maximum optimum water content and maximum dry density respectively. As explained earlier in figure 4 , granular materials of base course will be replaced by WPCC in percent of $50 \%$ by weight. Furthermore the mixed aggregate also have stabilized by cement with percent of $7 \%$, and $15 \%$. Stand up on effect of these parameters on Procter test results. Figure 7 shows average compaction test results of mixed aggregate as compared with that pure aggregate CTB for dry density and O.W.C. the density of CTB with aggregate contain $50 \%$ of WPCC although the density of pure aggregate is higher for $0 \%$ cement added, it was lower by approximate $4 \%$ for $7 \%$ cement content then, density approach each other at $15 \%$ of cement. This behavior of material give an indication about using WPPC will cause weakness of base course layer unless using cementation material such as Portland cement. On the other hand, using of cement as stabilizer need to investigate for finding an optimum percent adding according to what engineering property need to improve. Optimum water content emphasized the same conclusion but in reverse trend.

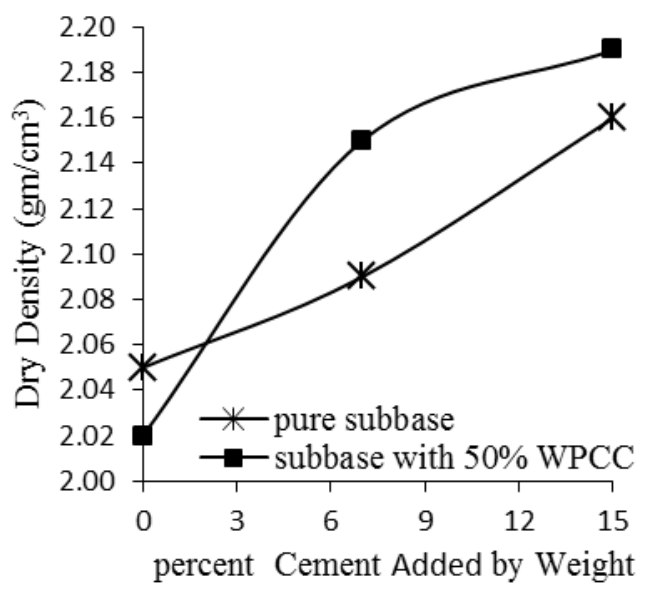

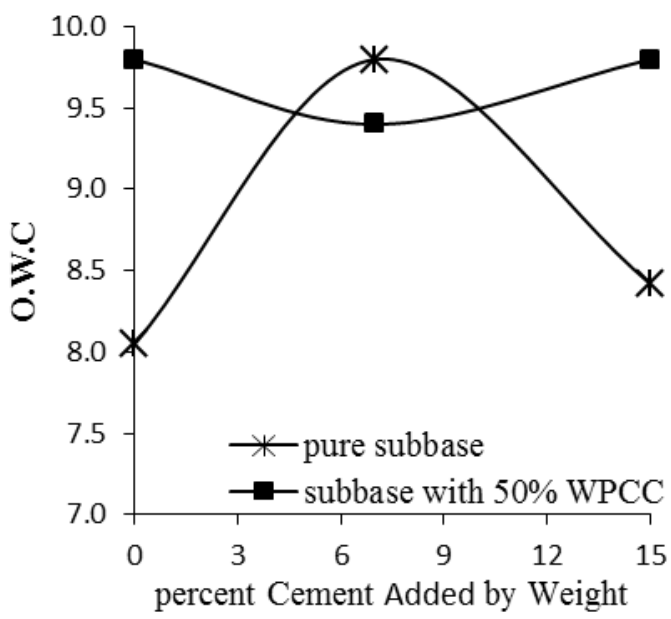

Figure 7: Effect of Using 50\% WPCC in CTB on The Compaction Test results

Compression strength under curing age 3,7 , and 28 days are shown below in figure 8 , each figure contain the corresponding strength for pure base course aggregate CTB. All figures gave lower compressive strength for the three ages for CTB contain $50 \%$ WPCC from that had pure base course aggregate.
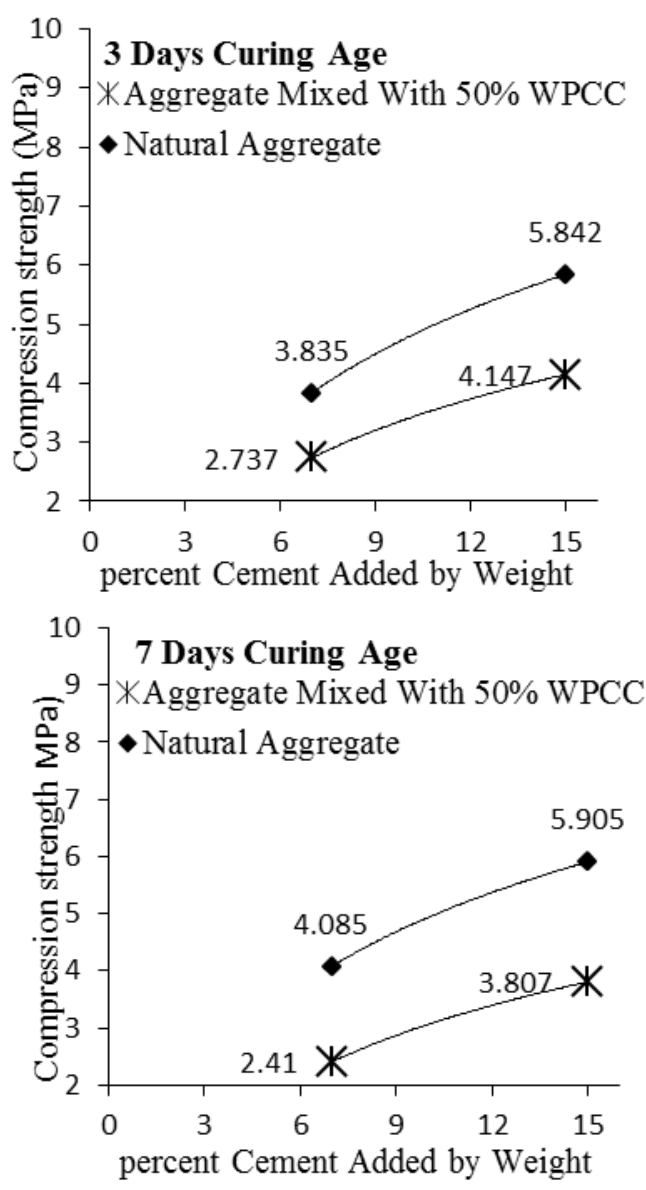


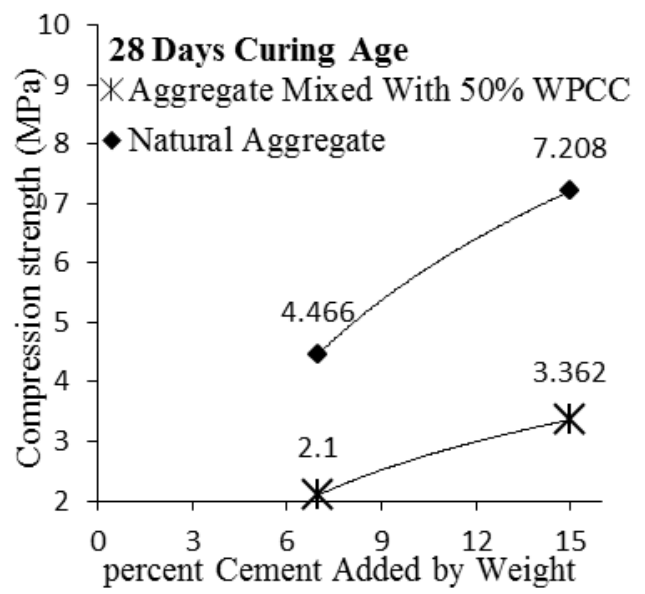

Figure 8: Effect of Using 50\% WPCC in CTB on Compression Strength Test Results

The effect of soaking in water on CTB compression strength values for different time periods selected to be one, two, and four weeks shown in figure 9 below for curing of 3, 7, and 28 days respectively. Aggregate when soaking in water the resulting CTB will be weakness in compression strength as compared with unsoaked samples. Furthermore, it became stronger and having a higher compression strength by complete curing process until reach 28 days.
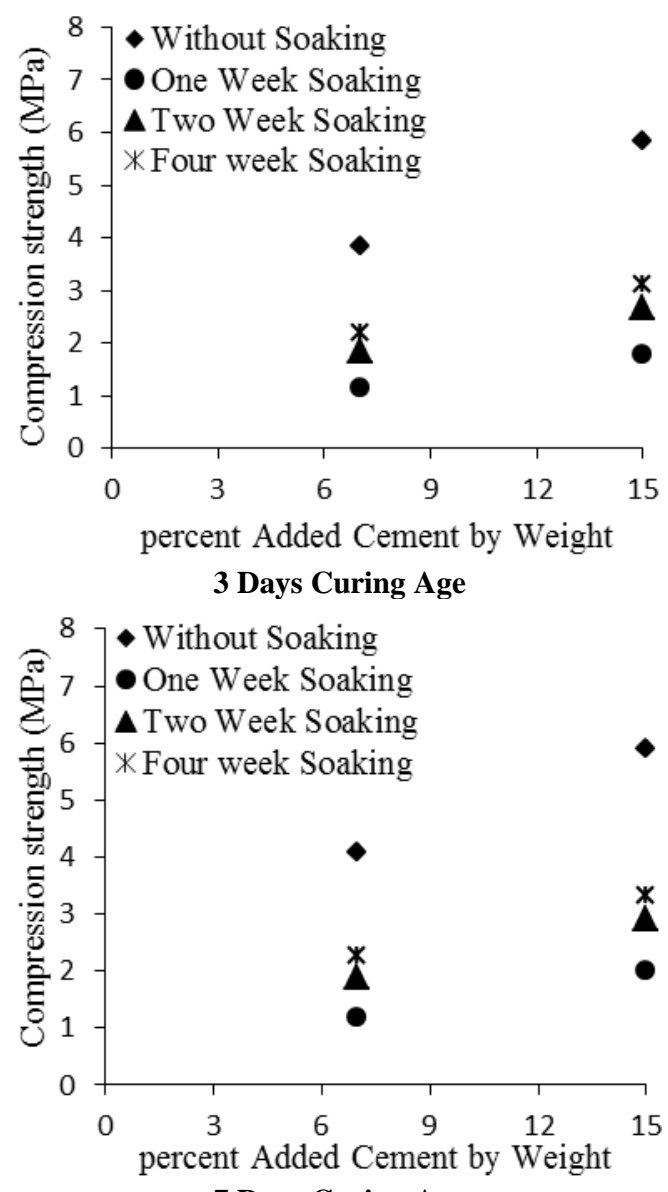

7 Days Curing Age

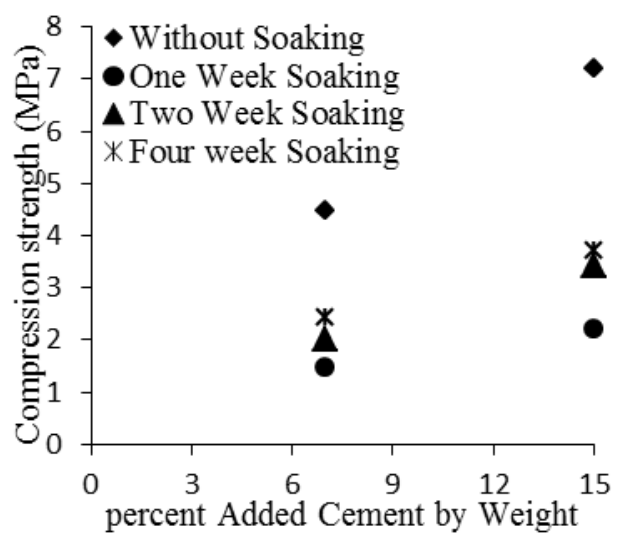

28 Days Curing Age

Figure 9: Effect of Soaking for Different Time Period on CTB Compression Strength Test Results

\section{Conclusions}

Based on the experimental results presented above, and on the basis of the observations made in the present work, the following conclusions can be set:

CTB showed continuous increasing in dry density with increasing of cement content in rate about $3.24 \%$ as average from initial value.

The CTB optimum water content increase with increasing cement content until reaching such value around $7 \%$ then began to decrease with increasing cement content.

compression strength of CTB increase continuously by increasing cement percent and curing periods.

The density of CTB with aggregate contain 50\% of WPCC was higher by approximate $4 \%$ for $7 \%$ cement content form CTB of pure aggregate. While, density approach each other at $15 \%$ of cement content.

CTB containing 50\% WPCC, compressive strength for the three ages $(3,7, \& 28$ days) are lower than that had pure base course aggregate.

Soaking base course aggregate in water gave CTB weakness in compression strength in small ages and it became stronger and having a higher compression strength by complete curing process until reach 28 days.

\section{References}

[1] AASHTO, (2007), Standard Specifications for Transportation Materials and Methods of Sampling and Testing, 5th edition, American Association of State Highway and transportation Officials, Washington, D.C., USA.

[2] AASHTO, (1993), AASHTO Guide for Design of Pavement Structures, American Association of State Highway and Transportation Official, Washington D.C.

[3] Al-Jummaily Mohammed A., Rasha. Abd Al-RedhaGhani, and Ahlam K. R. Al-Zerjawi, (2018), Study of Cement Treated Base Aggregate Properties For Pavement Structure, International Journal of Information Research and Review (IJIRR) Vol. 05, Issue, 01, pp.5093-5100.

[4] ASTM Standards, (2003), Roads and Paving Materials, Annual Book of the American Society for Testing and Materials Standards, Section 4, Vol. 04-03.

[5] Bezruk V. M., (1950), Soil-Cement Mixes; A New Structural Material. Cement Concrete in Road Construction., Moscow. 1950: 143-172.

[6] British Standard (1971), 12, British. Standards Institution. Portland Cement (Ordinary and Rapid Hardening), B.S.12: Part 2, B.S.I., London

[7] Bulletin, (1958), Cement Soil Stabilization, Highway Research Board, No. 198, Pub. 624.

[8] Chai, G., Oh, E., \& Balasubramaniam, B. (2005). In-Situ Stabilization of Road Base Using Cement, Presented at the 
International Offshore and Polar Engineering Conference, Seoul, Korea.

[9] George, Kalankamary Pily, (1963) Base course mix design criteria for cement-treated loess Retrospective, Theses and Dissertations. 2961.

[10] Gregory E. Halsted, David R. Luhr, Wayne S. Adaska (2006), Guide to Cement-Treated Base (CTB), Portland Cement Association.

[11] Guthrie, (2010), Variability in construction of CTB layers: material properties and contractor performance, W. Spencer Guthrie, Ph.D.

[12] Handy, R. L., (1958), Cementation of soil minerals with port land cement or alkalis, Highway Research Board Bulletin 198:55-64.

[13] India, (2016), Construction of cement stabilized subbase/Base, National rural roads development agency, Ministry of rural development Government of India.

[14] Korakod Nusit\& Peerapong Jitsangiam, (2016), Damage Behavior of Cement-Treated Base Material, Advances in Transportation Geotechnics. The 3rd International Conference on Transportation Geotechnics (ICTG 2016), Published by Elsevier B.V., Volume 143, 2016, Pages 161-169

[15] Liqun Hul, Jingxian Hao, Linbing Wang, (2014), "Laboratory evaluation of cement treated aggregate containing crushed clay brick", journal of traffic and transportation engineering, vol.1, issue 5, p.p. 371-382

[16] S.C.R.B., (2009), State Commission of Roads and Bridges (SCRB/R6), "General Specification for Roads and Bridges ", Republic of Iraq, Ministry of Housing and Construction, Department of Planning and Studies, Baghdad, Revised Edition ,Addendum No.3.,

[17] Shubber Khawla H.H, (2016), Comparison between Effect of Adding Asphalt Emulsion and Portland Cement on Engineering Properties of Sand River Subgrade Soil, 4th Intl. Conf. Advances in Civil, structural and Mechanical EngineeringUSA. Volume 3 issue 2 of "International Journal of Civil and Structural Engineering", pp. 12-16, CSM.

[18] Yang Sheng Yeo, (2011), Characterization of Cement Treated Crushed Rock Base course for Western Australian Roads, PHD thesis, Curtin University. 